\title{
The criminalization of indigenous people in Roraima state, Brazil: indigenous strategies to bring their rights into effect in the face of injustices and inequalities
}

\author{
Stephen Grant Baines' \\ 'Universidade de Brasília, Instituto de Ciências Sociais, Departamento de Antropologia, \\ Brasília/DF, Brasil
}

\begin{abstract}
The criminalization of indigenous people in the prisons of Roraima state, Brazil, is examined, in which the justice system, as throughout Brazil, has no mechanisms to identify indigenous people and recognize their differentiated constitutional rights, reinforcing the inequalities and injustices for indigenous people, the most oppressed and discriminated since colonial times. Over the past decade, indigenous organizations in the state capital have drawn attention to this problem and taken protagonist measures to try to change it. The Indigenous Council of Roraima (CIR), through their lawyer, Joênia Wapichana, elected, in 2018 the first Indigenous woman to be a federal deputy, set up a project to write down indigenous oral law so that it could be used locally to deal with criminal cases, encouraging indigenous communities to resolve accusations of crimes through councils of local leaders and thereby avoid them being handed over to the mainstream criminal justice system.
\end{abstract}

Key words: indigenous people, criminalization, colonial oppression, protagonist measures. 


\section{A criminalização dos povos indígenas no estado de Roraima, Brasil:}

estratégias indígenas para a efetivação de seus direitos diante das injustiças e desigualdades

\section{Resumo}

Examina-se a criminalização de indígenas nas penitenciárias do estado de Roraima, Brasil, no qual o sistema de justiça, como em todo o Brasil, não possui mecanismos para identificar os indígenas e reconhecer seus direitos constitucionais diferenciados, reforçando as desigualdades e injustiças para os indígenas, os mais oprimidos e discriminados desde os tempos coloniais. Ao longo da última década, organizações indígenas da capital deste estado têm chamado a atenção para esse problema e tomado medidas protagonistas para tentar mudá-lo. O Conselho Indígena de Roraima (CIR), por meio de sua advogada Joênia Wapichana, eleita, em 2018, a primeira indígena a ser deputada federal, montou um projeto para redigir o regimento indígena para que pudesse ser utilizado localmente para tratar processos criminais, incentivando as comunidades indígenas a resolver acusações de crimes por meio de conselhos de líderes locais e, assim, evitar que sejam entregues ao sistema de justiça criminal convencional.

Palavras-chave: Indígenas, criminalização, opressão colonial, medidas protagonistas.

\section{La criminalización de los pueblos indígenas en el estado de Roraima, Brasil:}

\section{estrategias indígenas para la cumplimiento de sus derechos frente a las injusticias y desigualdades}

\section{Resumen}

Se examina la criminalización de los indígenas en las cárceles del estado de Roraima, Brasil, en el que el sistema de justicia, como en todo Brasil, no cuenta con mecanismos para identificar a los indígenas y reconocer sus diferentes derechos constitucionales, reforzando las desigualdades e injusticias para los indígenas, los más oprimidos y discriminados desde la época colonial. Durante la última década, las organizaciones indígenas de la capital de este estado han llamado la atención sobre este problema y han dado pasos clave para tratar de cambiarlo. El Consejo Indígena de Roraima (CIR), a través de su abogada Joênia Wapichana, elegida en 2018 como la primera mujer indígena en ser diputada federal, puso en marcha un proyecto de redacción del regimiento indígena para que pueda ser utilizado localmente para atender casos penales, alentando comunidades indígenas para resolver los cargos por delitos a través del asesoramiento de líderes locales y así evitar que sean entregados al sistema de justicia penal convencional.

Palabra clave: indígenas, criminalización, opresión colonial, medidas protagonistas. 


\title{
The criminalization of indigenous people in Roraima state, Brazil: indigenous strategies to bring their rights into effect in the face of injustices and inequalities
}

\author{
Stephen Grant Baines
}

\section{Introduction}

I have been doing research in anthropology in the North Amazon region since 1982, when I started fieldwork for my PhD at the University of Brasilia (UnB) with the Waimiri-Atroari people (Amazonas/Roraima) (19821985)'. In 2001, I started research with Macushi and Wapishana peoples who live along the Brazil-Guyana border, within the field of studies on Ethnicity and Nationality on Borders, introduced in Brazil by Professor Roberto Cardoso de Oliveira (2005). In late 2007, I was invited by the Brazilian Association of Anthropology (Associação Brasileira de Antropologia - $A B A$ ), to coordinate a survey on the situation of indigenous people in prisons in the state of Roraima ${ }^{2}$.

The survey in Roraima state was carried out between early 2008 and early $2009^{3}$ (Baines, 2009). Since then I have continued this research with annual visits to Roraima state in the north of the Brazilian Amazon. The process of criminalization of indigenous peoples in Roraima, as in other states of Brazil, brings disastrous consequences for those indigenous people imprisoned, the majority of whom are among the poorest, most vulnerable and disadvantaged people in Brazilian society, reinforcing enormous inequalities and injustices as I argue below.

I have approached the theme of the criminalization of indigenous people in Roraima in previous articles (Baines, 2009, 2016a, 2016b), and my object here is to evaluate some of the changes that have occurred from 2008 until 2020, the crisis in the prison system with a rapidly increasing prison population which the State has been incapable of controlling, extreme overcrowding in prisons, the infiltration of organized crime within prisons, and the resulting reinforcement of inequalities and injustices brought about by criminalizing and imprisoning indigenous people. I look also at some of the indigenous strategies to start to deal with this situation through the protagonism of indigenous organizations.

\footnotetext{
1 Under the academic supervision of professor Julio Cezar Melatti, Department of Anthropology, University of Brasília.

2 Part of a larger survey which included three other states, coordinated by professor Cristhian Teófilo da Silva, then treasurer of the ABA, through an agreement between the ABA and the Higher School of the Federal Prosecution Service (Escola Superior do Ministério Público Federal - MPF)ABA/ESMPU (Associação Brasileira de Antropologia/Escola Superior do Ministério Público da União), "Criminalização e situação prisional de Índios no Brasil” (edital projeto de pesquisa ESMPU No. 19/2006). Relatório final convênio: Procuradoria Geral da República (PGR), Associação Brasileira de Antropologia (ABA). Coordenador: Cristhian Teófilo da Silva (ABA, UnB), Brasília, Distrito federal, maio 2008.

3 ABA/ESMPU (Associação Brasileira de Antropologia/Escola Superior do Ministério Público da União), "Processos de criminalização indígena em Roraima/Brasil” (número do formulário: 2008.2.1.1.297). Edital projeto de pesquisa ESMPU No. 98/2007. Relatório final convênio: Procuradoria Geral da República (PGR), Associação Brasileira de Antropologia (ABA). Coordenadores: Stephen G. Baines (UnB) \& Cristhian Teófilo da Silva (ABA, UnB), Brasília, Distrito Federal, março 2009.

The survey in Roraima was conducted within my research project focusing indigenous people on the international border, in early 2008 and early 2009 , with resources from my research scholarship from the National Council for Scientific and Technological Development (Conselho Nacional de Desenvolvimento Cientifico e Tecnológico- $\mathrm{CNPq}$ ), being an offshoot of my research project on indigenous people on the international border. The survey also included the participation of two post-graduate students in anthropology from the University of Brasília, Alessandro Roberto de Oliveira (UnB) e Walison Vasconcelos (UnB), in July 2008, with resources from the ESMPU.
} 
Before looking at the criminalization of indigenous people, it is necessary to outline the current plight of indigenous peoples in Brazil. Since 2019, the Brazilian government of president Jair Bolsonaro is threatening indigenous rights, with aggressive measures to reduce their autonomy, sell off their territories for logging, mining, highway projects and hydroelectric schemes, and implement policies of "forced assimilation", similar to government indigenist policies of the military dictatorship (1964-1985). President Bolsonaro is encouraging the invasion of indigenous territories and attacks against communities, promoting "forced integration", pushing a mining bill which would open up indigenous territories to large-scale mining, and to agribusiness, supporting the "marco temporal" an unconstitutional figure, supported by the ruralist bench in Brazilian congress, which stipulates that if indigenous peoples were not living on their land on 5 October 1988 - the date of Brazil's most recent constitution - they do not have the right to live there. It does not take into consideration the fact that many indigenous peoples had been forcibly dislocated from their lands, and also, up to the 1988 Constitution, indigenous people could not defend their rights legally being under State tutelage.

The government is also facilitating the spread of the Covid-19 pandemic in indigenous territories by failing to present an adequate plan to protect them from invaders as well as refusing to provide adequate health care plans to combat the virus in indigenous communities. At the same time the reduction of funding for the National Indian Foundation (Fundação Nacional do Índio - FUNAI) and dismantling of environmental policies provide further threats to indigenous rights.

The force of indigenous organization in taking action to bring into effect indigenous rights has become very clear during the pandemic of Covid-19. In Roraima, as in all other regions of Brazil, without adequate government support, many indigenous communities have established their own sanitary barriers to try to prevent the spread of the virus in their villages, although the pandemic is affecting many villages despite their efforts. Thirty eight sanitary barriers are mentioned by the Indigenous Council of Roraima (Conselho Indígena de Roraima - CIR $)^{4}$ on 19/07/2020, which were installed at access points to the communities. They have also taken other emergency measures such as providing basic kits to protect people from the virus and food baskets. The principal national-level indigenous organization in Brazil, the Articulation of Indigenous Peoples of Brazil (Articulação dos Povos Indígenas do Brasil - APIB) created by the indigenous movement at the 2005 "Free Land Camp" (Acampamento Terra Livre - ATL), the national mobilization which has been organized every year since 2004, to make visible the situation of indigenous rights, and to claim from the Brazilian State that the lawful demands of Indigenous peoples be attended to, together with several other indigenous organizations, has denounced the government of president Jair Bolsonaro for practicing genocide due to its complete neglect of indigenous peoples, and the president's incentives to invade indigenous lands, supporting agricultural expansion on indigenous territories, invasions by miners, and destructive, exploitative and predatory policies towards natural resources and the environment.

From 2005, the APIB, has become the main national indigenous mobilization struggling against powerful economic interests to bring into effect indigenous rights. On July 8, 2020, Minister Luís Roberto Barroso of the Supreme Federal Court (Supremo Tribunal Federal - STF), determined, within the scope of the "Claim of Non Compliance with Fundamental Precept N. 709" (Arguição de Descumprimento de Preceito Fundamental - ADPF N. 709) (BRASIL, 2020), one of the actions that are part of the concentrated control of constitutionality, filed on 06/30/2020 by the APIB represented by seven indigenous lawyers, with the support of six political parties,

4 Conselho Indígena de Roraima (CIR), 19/07/2020, "Quarta Fase: Campanha emergencial do CIR leva ajuda a 38 barreiras de proteção de seis povos indígenas". In: 〈https://cir.org.br/site/2020/oz/19/quarta-fase-campanha-emergencial-do-cir-leva-ajuda-a-38-barreiras-de-protecao-de-seis-povos-indigenas/>. Access on 12/09/2020. 
(PSB, PSOL, PCdoB, Rede, PT, PDT5), in which the negligence of the federal government in the fight against Covid-19 among indigenous people was emphasized, that the federal government adopt a series of measures to combat Covid-19 contagion and mortality among the indigenous population. As the APIB shows, the deliberate omission in the face of the well-known vulnerability of indigenous peoples characterizes a genocidal policy. This historic legal action, proposed by the APIB, led the Minister Barroso to defer an injunction for the implementation of measures to safeguard indigenous peoples during the pandemic. Among the measures are the planning with the participation of communities of actions to contain invaders on Indigenous Lands and the creation of sanitary barriers in the case of indigenous people in isolation or recent contact, and access of all indigenous people to the government Indigenous Health Subsystem (Subsistema de Atenção à Saúde Indígena do Sistema Único de Saúde - SASI-SUS), including those indigenous people in urban areas, and the elaboration of a plan to confront and monitor Covid-19.

In face of non-compliance with the measures demanded by the APIB, the same STF minister determined, on August 7, 2020, that the federal government complement the Sanitary Barriers Plan for Isolated and Recent Contact Indigenous Peoples as a measure to contain the spread of Covid-19 in the villages. On October 22nd, 2020, Minister Barroso again denied a second government plan to contain Covid-19, as inappropriate, and ordered the federal government to draw up a new General Plan for Coping and Monitoring for indigenous peoples. For the third time, Minister Barroso denied the version of the General Plan to Face the Covid-19 for Indigenous People on December $21^{\text {st }} 2020$ and determined that a new document be presented by January $8^{\text {th }}$ 2021, since the third plan presented by the government remains generic and inadequate. The Minister Barroso, finally partially approved, on March 3rd 2021, the General Plan to Face Covid-19 for Indigenous Peoples presented by the federal government, affirming that there was a profound disarticulation of government organs involved in the elaboration of this document, and his decision to partially approve it so that lives could be saved.

In the midst of the pandemic, at the IV Regional Assembly of the Raposa Serra do Sol Indigenous Land, held in Roraima on February 17-20, 2020, the leaders released a letter denouncing a new invasion of this Indigenous Land by placer miners ${ }^{6}$, an invasion motivated by the expectation generated by the proposal of president Jair Bolsonaro to legalize mining on Indigenous Lands. The actions of the APIB, the CIR, the Coordination of Indigenous Peoples of the Brazilian Amazon (Coordenação das Organizações Indígenas da Amazônia Brasileira - COIAB), other indigenous organizations, and the Mixed Parliamentary Front in Defense of the Rights of Indigenous Peoples (Frente Parlamentar Mista em Defesa dos Direitos dos Povos Indígenas'), launched by the Federal Deputy Joênia Wapichana on 08/04/2019, reveal that indigenous peoples are only successful, pressuring this government to provide basic emergency health services, as the pandemic spreads, through the protagonism of their political organizations. This Parliamentary Front elaborated the Law Project № 1.142/2020, which deals with measures of social protection to prevent the dissemination of the Covid-19 in indigenous territories and creates an Emergency Plan to Cope with this virus in indigenous territories, among other measures.

Faced with a government openly hostile to indigenous, quilombolas and other traditional peoples, which systematically violates the rights of these people, indigenous organizations are acting at various levels to claim their rights, from actions at the STF, the Federal Public Ministry (Ministério Público Federal - MPF),

\footnotetext{
5 PSB, Partido Socialista Brasileiro (Brazilian Socialist Party); PSOL, Partido Socialismo e Liberdade (Socialism and Liberty Party); PCdoB, Partido Comunista do Brasil (Communist Party of Brazil); Rede, Rede Sustentabilidade (Sustainability Network); PT, Partido dos Trabalhadores (Workers' Party); PDT Partido Democrático Trabalhista (Democratic Labour Party).

6 Conselho Indígena de Roraima (CIR), 24/02/2020, “Povos Indígenas divulgam carta contra o garimpo em T.I Raposa Serra do Sol”. In: < https://cir.org.br| site/2020/02/24/povos-indigenas-divulgam-carta-contra-o-garimpo-em-t-i-raposa-serra-do-sol/> Access on 12/09/2020.

7 The Mixed Parliamentary Front in Defense of the Rights of Indigenous Peoples, is made up of 237 members, including 210 Federal Deputies and 27 Senators. In $\langle$ http:||frenteparlamentarindigena.com.br/> Access on 20/10/2020.
} 
and within congress through the Parliamentary Front, down to local actions to implement sanitary barriers, fundraising for basic food baskets and the purchase of hospital and protective material for distribution to indigenous communities.

Data on the number of indigenous people who have died from Covid-19 in the prison system in Roraima have not yet been released. Regarding the criminalization and imprisonment of indigenous people, over the past decade, indigenous organizations have been adopting strategies to face this problem, specifically the CIR, created in 1990, from previous initiatives of indigenous political organizations in Roraima, whose objective is to guarantee constitutional rights and to strengthen the autonomy of indigenous peoples in Roraima. The CIR undertakes activities in the field of health, education, culture, environmental management, social promotion, sustainable development and participation in public policies, respecting the social and cultural organization of the different indigenous peoples within Roraima state. The CIR has become one of the most active indigenous organizations in Brazil, locally, regionally, nationally and internationally. Another indigenous organization, the Organization of Indigenous People in the City (Organização de Indigenas da Cidade - ODIC), founded in 2005, has as its principal objective the defense of indigenous rights in the city of Boa Vista, the state capital, in view of the fact that the FUNAI has given little attention to indigenous people who live in cities, focusing on those who live on demarcated Indigenous Lands (Terras Indigenas). Both the CIR and the ODIC, in recent years, have drawn attention to the criminalization of indigenous people and taken measures to try to change the critical situation of indigenous people in prison. The CIR, through their lawyer, Joênia Wapichana, who has been elected, in 2018, the first indigenous woman to be a federal deputy and the second indigenous deputy ever elected in Brazil, set up a project to write down indigenous oral law so that it could be used locally to deal with criminal cases, encouraging indigenous communities to judge their own people through their local Council of Tuxauas (local leaders) and thereby avoid handing them over to the mainstream criminal justice system. The ODIC also works toward making indigenous people in the city conscious of their legal rights.

The FUNAI, despite being grossly underfunded, has also taken initiatives to investigate the serious situation of indigenous people in prisons, starting with a visit made by a team from the ombudsman of the organ in October 2014 to the Monte Cristo Agricultural Prison ${ }^{8}$. Some indigenous lawyers and one indigenous judge have also shown concern over the criminalization of indigenous peoples (Eloy Amado, 2020). The most effective results are coming from indigenous people themselves, who through their protagonism are working to change a desperate situation.

\section{Theoretical guidelines}

To examine the situation of indigenous people in prisons, the notion of "total institution", of Erving Goffman (1990 [1974]) is useful to describe a situation in which there is "a basic division between a large controlled group, that we can denominate the inmate group, and a small supervision team" (1990: 18). However, in dealing with indigenous people it is necessary to take into consideration the specificities of ethnic differences and the institutionalized racism of the national society, constructed over centuries in colonial and neocolonial situations, where indigenous people have been the most oppressed of the oppressed in a national society with immense social inequalities and injustices, a legacy of the coloniality of power (Quijano, 2000), racism which permeates all government institutions, including the prison and justice systems.

\footnotetext{
8 "Funai starts a survey on Indians imprisoned in Roraima: Ombudsman of the organ visited the Agricultural Prison this Tuesday (14). State is the first visited by the team; work will serve as a model”. (Funai inicia levantamento sobre índios encarcerados em Roraima: Ouvidoria do órgão visitou a Peniten ciária Agrícola nesta terça-feira (14). Estado é o primeiro visitado pela equipe; trabalhos servirão de modelo), 14/10/2014. 〈http://g1.globo.com/rr/roraima/ noticia/2014/10/funai-inicia-levantamento-sobre-indios-encarcerados-em-roraima.html> Access on 10/o9/2020.
} 
Looking at the colonial history of this region, the imprisonment of indigenous people is nothing new. In the second half of the XVIII century, the Portuguese military occupation of what is now Roraima, was carried out by capturing indigenous peoples and subjecting them to discipline in settlements which shared the characteristics of a colonial "total institution" (Goffman 1974). Indigenous people from different ethnic origins were forcibly put together in "multiethnically composed settlements", described by Nádia Farage (1991: 125), who argues that the process of colonization met with strong resistance from the autochthonous population with a series of uprisings against the "overexploitation of the labor of settled Indians" (Farage, 1991: 131) and massive breakouts, that spread through these settlements "in proportion to the violence used by the Portuguese to repress them" (Farage, 1991: 131). After the repeated failure by the Portuguese military forces to keep indigenous people in these settlements along the Rio Branco, they began sending them to serve as slave labour in distant parts of the Amazon basin where escape and return to their villages were impossible. During the XIX century, Paulo Santilli (2002) describes illegal expeditions to enslave indigenous people in this region, long after indigenous slavery had been banned in the Amazon basin in 1755. This author reveals that "slavery continued in the form of private expeditions that counted on the active support of government representatives in the area to recruit indigenous labour for rubber extraction" (Santilli, 2002: 493) in the forests of the lower Rio Branco. Santilli (2002) describes how these nineteenth-century slavery expeditions were internalized in Macushi cosmology, which saw non-indigenous settlers as cannibals who took indigenous people downstream, from where most never returned, the victims of violent exploitation by forced labour and diseases that consumed their bodies. As a consequence of these slave raids, indigenous peoples fled from contact with white people. These settlements, part of an attempt to enslave indigenous people, in a different epoch and on a smaller scale, were not very different from modern prisons which aim to "reeducate" detainees and transform them into an obedient labour force to serve the State.

The notion of prison-institution of Michel Foucault (1995 [1979]), in which this author, from a universalist perspective which does not take into account ethnic and racialized differences within this institution in colonial situations is, however, useful for describing the universalist policies of the national society to which indigenous people are submitted, disregarding their differentiated constitutional and international rights and treating them as part of an idealized homogenous Brazilian society where "all are equal", blatantly ignoring the racialized and class inequalities that characterize Brazilian society. Foucault describes the prison-institution in which,

procedures were being elaborated for distributing individuals, fixing them in space, classifying them, extracting from them the maximum in time and forces, training their bodies, coding their continuous behaviour, maintaining them in perfect visibility, forming around them an apparatus of observation, registration and recording, constituting on them a body of knowledge that is accumulated and centralized. The general form of an apparatus intended to render individuals docile and useful, by means of precise work upon their bodies... (1995: 231).

Foucault adds that "the prison must be an exhaustive disciplinary apparatus ... it gives almost total power over the prisoners; it has its internal mechanisms of repression and punishment: a despotic discipline" (1995: 235-236) and that "Although it is true that prison punishes delinquency, delinquency is for the most part produced in and by an incarceration... The delinquent is an institutional product (1995: 301).

Indigenous prisoners, like non-indigenous prisoners, are broken down through being subjected to the brutal violence of the prison situation and its disciplinary procedures, as many indigenous people commented, in phrases such as, "Once they are put inside, there is little hope of recovery", "When they go into prison, there is little more we can do for them". For this reason many indigenous prisoners and indigenous people commenting on them, stress the need to create alternative community measures and a separate wing of the prison reserved for those indigenous people whose situation cannot be solved within their communities. 
In an undergraduate dissertation, Jonildo Viana dos Santos, focuses the prison system in Roraima, and affirms that "Today it is notorious that the prison is a school for the maintenance, reproduction and even perfection of criminal conduct." (2004: 63) (author's translation).

Among research done in anthropology in Brazil, Cristhian Teófilo da Silva draws attention to the fact that "The criminalization and the penal situation of indigenous people have not been problematized in Brazil in the same proportion that has occurred in countries like Australia, Canada and New Zealand... (2009: 209) (author's translations) and that "The imprecision of official information and the scarcity of research on the theme has contributed to making this problematic invisible..." (2009: 209). This author adds that, "the criminalization and prison situation of indigenous people in Brazil must be resized as problems of a juridical order..." (2009: 221). In another article, this author affirms the necessity of dealing with the problem of the criminalization of indigenous people in Brazil and their prison situation from a multidisciplinary approach, due to the fact that "no discipline or sub-discipline of the Social Sciences has accepted the theme" (Teófilo da Silva, 2013: 139). He goes on to propose, "the elaboration of a wider concept of criminalization for us to approach, in an ever more methodical and systematic way, the main characteristics involving the problematic of indigenous people in prison, whether men or women" (2013: 152), and proposes, from studies undertaken in Brazil which he examines in this article, that it is necessary to distinguish between two groups of data which emerge from facing this reality in these studies, "a first order of data on issues of criminological character, while the second order of data emerges from problems referring to the operability of criminal justice in Brazil” (2013: 153).

In his master's dissertation in Law at the University of Brasilia, Tédney Moreira da Silva (2015) examines the juridical-penal treatment of indigenous peoples, considering that penal law is the instrument which the State frequently uses to solve social problems, and stresses that the criminalization of indigenous people fits into the secular context of the formation of the Brazilian nation by means of the suffocation of alterity. $\mathrm{He}$ concludes that a revision of the criminalization of indigenous people should be undertaken by the agencies of the present penal system, and presents a series of recommendations.

In his master's dissertation in Social Anthropology at the Federal University of Amazonas, Felipe Pereira Jucá (2019), argues that imprisonment is used as a primordial way of supposedly solving conflicts and also, frequently, as a purely disciplinary method even when there is not a formal accusation. His research reflects on the penal responsibility of indigenous people, exposing the contradictions and mistakes observed among the legal dispositions with a supposed justice undertaken by the Judiciary Power. A lawyer by academic formation, he turns to anthropology to unite theoretical elements which discuss and question the legitimacy of the established powers and the structures of punishment of the State which reflect the monopoly of physical and symbolic violence. He relates that he had been invited by the Public Defender's Office in Amazonas State to work in São Gabriel da Cachoeira, in Northwest Amazonas, with the purpose of providing legal assistance to the low-income population, until a public defender was appointed for that task. The crucial point he emphasizes is that the penal question in Brazil has not passed through a qualified and scientifically rigorous debate to take into account the ethnic asymmetries and the relations between traditional peoples and agencies of control and punishment of the State in a colonial situation. Intellectuals and operators of the law reproduce the same evolutionist knowledge when they refer to indigenous peoples.

\section{Indigenous people in the prison system in Roraima}

An important issue in research on indigenous people in the prison system of Roraima, and other regions of Brazil, is that many prisoners do not identify themselves as such; many from fear of being further discriminated. As I frequently heard in my interviews, as poor people and also indigenous they face a double discrimination by other prisoners and by prison staff. Some told me that they preferred not to identify as this could make 
their situation even worse. Some prefer to not identify as indigenous in public spheres such as life in prison, and only do so when they are socializing with their relatives, friends and other indigenous people. However, over the years since I started this research, the number of indigenous people willing to identify has increased considerably, in attempts to bring into effect their differentiated rights.

The fact that many people do not choose to identify as indigenous can also be explained, in part, by the context of Brazilian society with its plethora of identities, where many ethnic identities are subsumed under the National Census category "brown" (cor parda). João Pacheco de Oliveira emphasizes that "In the North (of Brazil) ... the 'brown' category [of the National Census] evokes predominantly indigenous ancestry or identity" (1999: 134), in contrast to some other regions of Brazil where it evokes Afro-Brazilian ancestry or identity. In the prison system of Roraima, I have interviewed indigenous people who publically claimed their ethnic identity but faced prejudices from prison staff and other prisoners since they did not have an "indigenous appearance" according to common sense ideas about how an indigenous person should look. Soraya ${ }^{9}$ told me, "Just because I am light skinned and have a better education than most indigenous prisoners, nobody believes I am indigenous, but I was brought up in the Surumu ${ }^{10}$. My mother is Macushi and my father is non-indigenous from the Northeast of Brazil".

Others, who the prison staff referred to as being indigenous, because of their phenotypes, did not see themselves as such, or were unclear about whether they could be indigenous. Paulo, a man at the semi-open detention centre, who other detainees told me I should interview if I wanted to interview indigenous people, told me that he was not sure if he could identify himself as indigenous, since although his father and mother were indigenous and born in villages on Indigenous Lands, he had been brought up in Boa Vista and had never lived for long periods in villages. However, after talking for about one hour, when he understood that I would not discriminate him for being indigenous he admitted, "I suppose I am indigenous, as Mummy and Daddy were indigenous". Some people understood that being indigenous required living in villages in rural areas and, since they had been brought up in the city, did not think that they could be considered indigenous, a popular regional stereotype which contributes to making indigenous people in cities invisible, denying their existence. A few did not know their ancestry, such as Iracema, in the Female Jail, who was referred to as "a real Indian" by some of the prison staff, because of her physical appearance and name ${ }^{11}$. She identified herself as such because, as she related to me, she had been told that her parents were indigenous from Amazonas state, but she did not know their ethnic groups, since they had both died when she was very young.

As regards the category "brown" (pardo) of the Brazilian national census, used also in the prison system, Pacheco de Oliveira affirms that,

The category "brown" (pardo") is a generic indicator for mixing between different colour groups. This is not at all the meaning of the condition of indigenous people, which refers to a differentiated legal status, not to a situation of alleged internal homogeneity and external distinctiveness as to colour. In declaring himself as "indian" or "indigenous", the person being interviewed for the National Census is not intending to include himself in a classification as to colour, but to speak of the specificity of his rights and his relationship with the State. By maintaining a form of social organization and cultural traditions that he considers to come from pre-Colombian populations, he self-identifies himself as "indigenous" and demands a different treatment from the State... (Pacheco de Oliveira, 1997: 69).

\footnotetext{
9 I use pseudonyms to preserve the anonymity of the prisoners.

10 The community of Surumu is localised in the Raposa Serra do Sol Indigenous Land.

11 "Iracema" is the name of a character in the romantic novel, of the same name, published in 1865 by José de Alencar. The first novel of Alencar's "Indianist Trilogy", that focused on the foundations of the Brazilian nation was "The Guarani", published in 1857, followed by "Iracema", and finally by "Ubi rajara" in 1874. In the novel, "Iracema", Alencar tries to remake the history of the Brazilian colonial state of Ceará, with Moacir, the son of the indigenous woman, Iracema, and the Portuguese colonizer, Martim, as the first true Brazilian in Ceará.
} 
It is important to remember too, that in Brazil, the term "Indigenous Land" is a juridical category which designates lands of traditional use and occupation by indigenous peoples, demarcated by the federal government, which they need to maintain their ways of life, according to Article 231 of the Federal Constitution (1988). In Brazil, a total of $1.173 .776 \mathrm{~km} 2$ or approximately $13.8 \%$ of the land surface have been demarcated as "Indigenous Lands" (2021), although many of these demarcated lands have been invaded and occupied by non-indigenous people ${ }^{12}$ and many have not had their demarcation process completed, nor even started. In Roraima, a Brazilian state which has the largest population of indigenous peoples in relation to non-indigenous, "Indigenous Lands" make up a total of 10.370 .676 hectares or $46.20 \%$ of the land surface of this state. However, less than fifty years ago most of Roraima consisted of indigenous territories. Throughout the northeast of Roraima state, the invasion of indigenous territories and the demarcation of small fragmented Indigenous Lands by the FUNAI in the 1980s, with the exception of the three larger Raposa Serra do Sol, São Marcos and Jacamim Indigenous Lands, has resulted in small overpopulated fragmented Indigenous Lands, with increasing populations and no further space to expand areas of cultivation, leading many young people to migrate to Boa Vista, where some are subjected to criminalization.

\section{Field research in Roraima}

In my investigation on the criminalization of indigenous people I focused my attention on indigenous people in the prison institutions in the capital, Boa Vista: the Monte Cristo Prison Farm (Penitenciária Agrícola Monte Cristo - PAMC), constructed in the late 1980 os to receive prisoners on semi-open regimes, but which has never undertaken agricultural activities and has been used for closed regime prisoners, is the largest prison in Boa Vista. The Boa Vista Public Female Jail (Cadeia Pública Feminina de Boa Vista-CPFBV) originally constructed near the PAMC, and later transferred to the suburb Asa Branca. The Boa Vista Public Jail (Cadeia Pública de Boa Vista - CPBV), the Hostel House Professor Aracelis Souto Maior (Casa do Albergado Professor Aracelis Souto Maior - CA), and the Centre for Prison Progression (Centro de Progressão Penitenciária - CPP).

I sought authorization to get access to the prison units and interview indigenous prisoners at the Prison System Department (Departamento do Sistema Prisional - DESIPE), localized administratively within the State Secretariat of Justice and Citizenship (SEJUC). I also spoke to people at the State Secretariat of Public Security (SESP); the CIR and the ODIC, which have, in recent years, been paying more attention to the criminalization of indigenous people in Roraima state, are very important sources to accompany the work of indigenous organizations in the city and in rural areas; the State Secretariat of the Indian (SEI); the FUNAI; the Diocese of Roraima; the Centre of Migration and Human Rights (CMDH); the Prison Pastoral of the Catholic Church; the Federal University of Roraima (UFRR), especially the Insikiran Institute for Indigenous Higher Education (Instituto Insikiran de Formação Superior Indígena); the Civil Police of Roraima State; and the Federal Police, in addition to some public defenders at the Public Defense Office.

The fieldwork methodology, in prisons, has been carried out in yearly visits to Roraima in January and February during the university recess, with ten period of fieldwork between 2008 until 2019, in which I dedicated from seven to ten days each year in conducting interviews with indigenous people inside prisons and with prison staff, law operators and other people involved with indigenous people in prison. The interviews were carried out following a script of questions, always leaving time for them to speak about issues they considered important. The interview conditions varied, sometimes inside prison libraries, in cells, in a church, and in prison administration offices, according to decisions made by the prison directors and administrators. Often I was allowed to interview indigenous prisoners alone, but sometimes under the surveillance of prison staff.

12 See Instituto Socioambiental, Localização e extensão das TIs $<$ https://pib.socioambiental.org/pt/Localiza\%C $3 \% \mathrm{~A}_{7} \% \mathrm{C}_{3} \% \mathrm{~A}_{3}$ _e_e_extens\%C $3 \% \mathrm{~A}_{3}$ ○_das_ TIs> (Access on 15/12/2020). 
The concept of total institution presented by Goffman (1974), of a large controlled inmate group, and a small supervision team, must be reformulated in the prison system in Brazil. In 2015, I was told at the Monte Cristo Agricultural Prison, that there were more than one thousand four hundred detainees in this unit at the time and often as few as nine members of the supervision team present, who had no means whatsoever of controlling the situation inside the prison. However, I was informed that internal control was maintained to some extent by the inmates own organization through the appointment of heads of prison wings, who were usually older prisoners appointed informally by the inhabitants of each wing of the buildings inside the prison to maintain some order within their wing.

I mention below some of the legislation to which indigenous people are subject, to emphasize that if this legislation were to be effectively applied, most indigenous people would not be in prisons, and the enormous gap between, on the one hand, a legislation which provides possibilities of respecting indigenous rights and, on the other hand, the everyday practices of the justice system, which make indigenous people invisible, denying their indigenousness, incorporating institutional racism and acting to deny their rights. Until indigenous organizations pressure to bring into effect the differentiated rights of indigenous people who are criminalized and imprisoned, and thereby bring into effect these rights, the legislation will remain a dead letter.

In Brazil, Indigenous people come under Law 6.001, 19.12.1973 (the Indian Statute), in which, according to Article 56,

In the case of the conviction of an Indian for a criminal offense, the penalty should be mitigated and in its application the Judge will also take into account the degree of integration of the Indian.

Single Paragraph. The sentences of imprisonment and detention shall be served, if possible, under a special semiopen regime, in the place where the federal agency for assistance to Indians has an office closest to the condemned man's residence.

Article 57 of this Statute, states that, "The application by tribal groups, according to their own institutions, of criminal or disciplinary sanctions against their members shall be tolerated, provided that they are not cruel or opprobrious, the death penalty being prohibited under all circumstances".

According to the Federal Constitution of Brazil of 1988,

Indians shall have their social organization, customs, languages, creeds and traditions recognized, as well as their original rights to the lands they traditionally occupy, it being incumbent upon the Union to demarcate them, protect and ensure respect for all of their property (Article 231).

Thereby, the Federal Constitution of 1988 guarantees to indigenous people the right to be different and to be treated differently, respecting their cultural differences. In the event of the execution of a custodial sentence or imprisonment of indigenous people, compliance with the provisions of Articles 56 and 57 of the Indian Statute is mandatory.

Indigenous people also come under international legislation which the Brazilian government is signatory to, such as the Convention 169 of the International Labor Organization (ILO). According to Article 10, Paragraph 2, in the case of imprisoned Indians "Preference must be given to other types of punishment than imprisonment".

\section{Inside prisons in Roraima}

The testimonies of indigenous prisoners shed light on the enormous injustices they face and lack of information about their differentiated rights, in addition to the racial discrimination they face from some prisoners, prison agents, police, prosecutors, public defenders and judges. Considering the disproportionately asymmetrical structure of interethnic relations that underlie the social, police and penal practices, in a region 
where the presence of indigenous people is conspicuous and racism is very strong, it is necessary to consider the obstacles that indigenous people face to have access to justice and to consider the possibilities of creating differentiated institutions with alternative penalties, respecting their constitutional rights and international legislation. The majority of indigenous people in prison identified as Macushi or Wapichana (Figure 1), the numerically largest ethnic groups in the northeast of Roraima who are in intense contact with the regional society. Many indigenous people interviewed did not understand why they were in prison, many waiting for years in preventive prison for their cases to be judged, often far beyond the time they would have served if they had been judged, in subhuman conditions. While some recognize that they have practiced a crime, many swear that they have been imprisoned unjustly with no recourse to defend themselves.

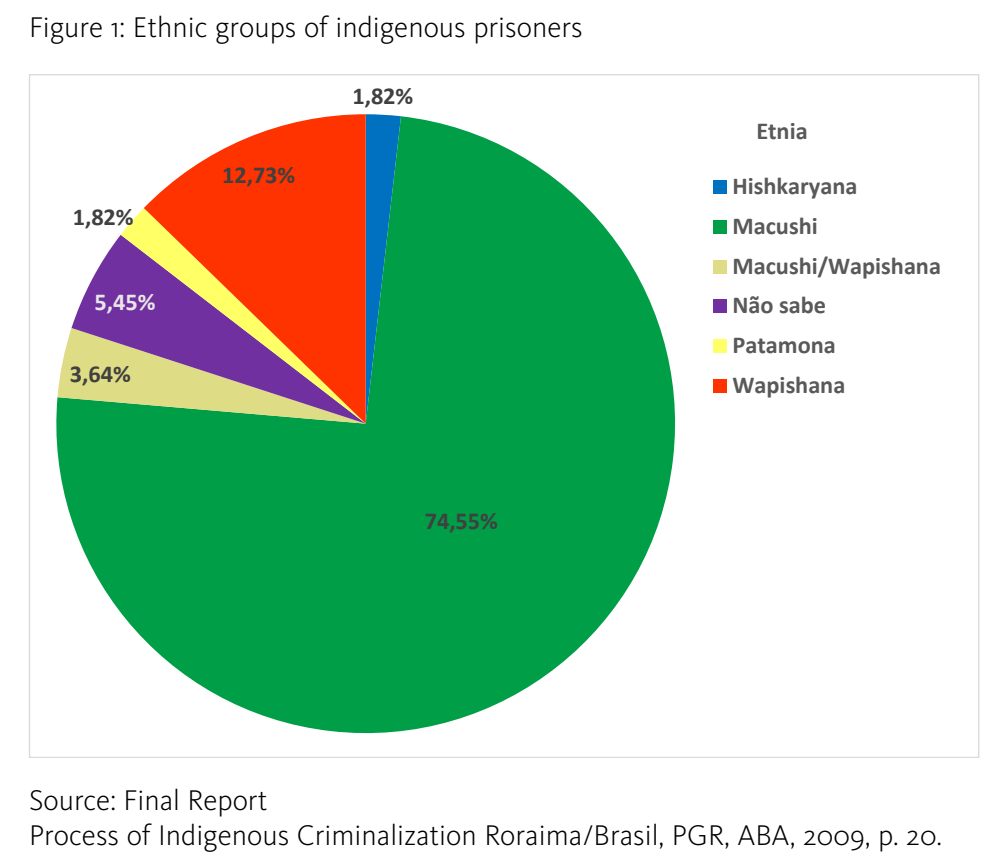

Some have been imprisoned for cultural misunderstandings such accusations of "rape of vulnerable" (girls under 14 years of age, according to Article 217-A of the Penal Code) when they allege that they were living in a marital relationship with young women with the agreement of the families concerned and according to their customs. Others, intimidated by the police and the legal system, could not make themselves understood and were imprisoned as a result of communication difficulties, including limited understanding of Portuguese, issues that I have approached in another publication (Baines, 2016b).

Prisoners who consider themselves poor, which includes most indigenous detainees, who cannot pay a private lawyer fees to help them get out of prison or have their sentence reduced, revealed the hopelessness and injustice of their situations, waiting to be judged (Baines, 2009) and not knowing how long they will be kept in limbo. Many were indignant for having been imprisoned unjustly and not given a chance to defend themselves against accusations of crimes they swear they had never committed. One man interviewed at the Monte Cristo Agricultural Prison, who suffered from a heart condition, told me that he had had a pacemaker implanted some years before, and that it was due to be replaced more than a year previously. However, his appeals to consult a doctor had been consistently ignored and he was suffering from fainting spells, "My heart condition is getting worse. I must have the pacemaker renewed. If not, I'm going to die here in prison". 


\section{The prison system in Brazil in recent years}

Over recent years the crisis of the prison system in Brazil has aggravated. The prison population has rocketed in critically overcrowded prisons, controlled by criminal factions, transforming Brazilian prisons into extremely violent institutions with frequent rebellions and massacres in which prisoners live in constant fear. In early 2017, a series of prison riots triggered one of the worst crises in the prison system, affecting especially the states of Amazonas, Roraima and Rio Grande do Norte. According to official data from the National Prison Information Survey (Infopen ${ }^{13}$ ), these three states have occupancy rates that far exceed their capacity. Amazonas has the rate of $484 \%$, Rio Grande do Norte $207 \%$ and Roraima, $195 \%$. While the total population of Brazil has more than doubled between 1970 and 2019, the prison population had more than trebled between 2000 and 2016 (Figure 2). Between December 2014 and June 2016, Brazil imprisoned nearly 100,ooo people, ranking the country as third in the world with the most people in prison, behind only the United States and China.

Figure 2: Population increase in Brazil and prision population

$\begin{array}{rrr}1960 & 70,119,071 & +35.0 \% \\ 1970 & 93,139,037 & +32.8 \% \\ 1980 & 119,002,706 & +27.8 \% \\ 1991 & 146,825,475 & +23.4 \% \\ 2000 & 169,799,170 & +15.5 \% \\ 2010 & 192,755,799 & +13.5 \% \\ 2019 & 210,354,000 & +9.1 \%\end{array}$

\begin{tabular}{|c|c|}
\hline \multicolumn{2}{|c|}{ PRISION POPULATION IN BRAZIL } \\
\hline 2000 & 232,755 \\
\hline June/2008 & 277,847 \\
\hline June/2010 & 494,237 \\
\hline June/2012 & 549,577 \\
\hline June/2014 & 607,731 \\
\hline June/2016 & 726,712 \\
\hline
\end{tabular}

Of these, $40 \%$ are pre-trial detainees on preventive regime ${ }^{14}$. Drug trafficking has become the crime responsible for most incarcerations: $28 \%$ of inmates, or 203,000 people. When I started research in 2008 , the prison inmate population for Roraima state was 1,435 of which 45 were registered as indigenous, while in June 2017 it had increased to 2,579 with 107 registered as indigenous, a grossly underestimated figure, considering that many prefer not to identify as indigenous and, by not classifying themselves as indigenous are classified by the police and prison staff under the amorphous category "brown" (pardo) (Figure 3 and 4). This is an official category of the Brazilian Census, associated with the idea of a mixed-race nation, which few people identify as. Government functionaries have no administrative guidance to identify prisoners according to their ethnic identity, a question frequently dismissed by non-indigenous prison staff and operators of the Law, under the phrase, "All are equal before the Law", leading to large numbers of indigenous prisoners being made invisible, and the denial of their differentiated rights. On June 25th, 2019, the Brazilian National Council of Justice approved Resolution No. 287, grounded on the United Nations Declaration on the Rights of

13 Infopen, <https://www.gov.br/depen/pt-br/sisdepen/mais-informacoes/relatorios-infopen> Access on 21/11/2020.

14 Ministério da Justiça e Segurança Pública, 08/12/2017, <https://www.justica.gov.br/news/ha-726-712-pessoas-presas-no-brasil > Access on 23/11/2020. 
Indigenous Peoples (2007), which establishes special procedures for the treatment of people who self-identify as indigenous in the process of trial, accusation and imprisonment, aiming to ensure the rights of this population in the criminal sphere of the Judiciary. This is an important step toward recognising indigenous peoples differentiated rights, but will need further measures for it to be brought into effect, especially pressure from indigenous organisations.

Figure 3: Prisoner profile/ Quantity of prisioners by skin colour/ ethnicity (Exemple of 80\%), June 2008

$\begin{array}{lccc} & \text { Male } & \text { Female } & \text { Total } \\ \text { White } & 200 & 40 & 240 \\ \text { Black } & 172 & 15 & 187 \\ \text { Brown ("de cor parda”) } & 815 & 71 & \mathbf{8 8 6} \\ \text { Yellow } & 1 & 0 & 1 \\ \text { Indigenous } & 37 & 8 & \mathbf{4 5} \\ \text { Other } & 0 & 0 & 0 \\ & & 1359 \\ \text { Source: InfoPen } & & \\ \langle\text { http://www.mj.gov.br/data/Pages/MJD574E9CEITEMIDC37B2AE94C6840068B1624D28407509CPTBRIE.htm>. } \\ \text { Access 15/05/2009. }\end{array}$

Figure 4: Prisoner profile/ Quantity of prisioners by skin colour/ ethnicity (Exemple of 80\%), June 2017

$\begin{array}{lccc} & \text { Male } & \text { Female } & \text { Total } \\ \text { White } & 144 & 25 & 169 \\ \text { Black } & 325 & 15 & 340 \\ \text { Brown (cor "parda") } & 1.321 & 112 & \mathbf{1 . 4 3 3} \\ \text { Yellow } & 1 & 0 & 1 \\ \text { Indigenous } & 101 & 6 & 107 \\ \text { Other } & 530 & 0 & 530 \\ & & & 2.579\end{array}$

Source: InfoPen

〈http://antigo.depen.gov.br/DEPEN/depen/sisdepen/infopen/relatorios-analiticos/RR/r/oraima〉. Access $02 / 09 / 2021$.

On the first day I visited the Monte Cristo Agricultural Prison in Boa Vista, in January 2008, as had been scheduled with the director of the Prison System Department (DESIPE), I was not allowed to enter, since two inmates had been murdered in a simulated hanging, and shock police invaded the prison to remove the corpses. The then director of the DESIPE, a military police captain, was arrested soon after for leading a criminal group within the prison accused of murdering prisoners. In more recent years, gang warfare of organized crime has broken out inside prisons and in early January 2017, fifty six prisoners were killed in the main prison at Manaus, Amazonas state, and five days later 33 inmates were killed ${ }^{15}$ on 6 January 2017 in the Roraima Monte Cristo Agricultural Prison which had a population of over 1,400 inmates at the time, double its capacity, some of which were decapitated. In late November 2018 a Federal Intervention Work-Force of 83

15 Agência Brasil, 06/01/2017, 〈https:/|agenciabrasil.ebc.com.br/geral/noticia/2017-01/roraima-33-pessoas-morrem-em-presidio > Access on 27/11/2020. 
federal agents occupied the Monte Cristo Agricultural Prison. The Penitentiary Intervention Task Force (FTIP), made up of federal agents, has been extended for the twelfth time, on 02 August 2021, for another 9o days until 31 October 2021, published in the Official Gazette (DOU) on 03 August 2021 ${ }^{16}$. Up to 2017, access to the Monte Cristo Agricultural Prison was relatively easy, although I experienced stronger surveillance each year; however, since that year I have been unable to interview indigenous prisoners in this prison. In 2017, the then director of the DESIPE showed me videos on his mobile phone of prisoners threatening to kill other prisoners if anyone entered the prison, and informed me that not even a doctor could enter to treat those prisoners who needed medical attention. After the Federal Intervention in 2018, I have been unable to enter this prison and my interviews of prisoners have been restricted to the other prison units. Since the prison rebellions in 2017, prisoners at the Public Jail have only been allowed to be interviewed in the office where they receive visits from lawyers, handcuffed with their hand behind their backs in a position of extreme discomfort, a technique of punishment (Foucault, 1979) aimed at deterring them from starting further rebellions.

\section{Some results of this research project}

When this research was started in 2008, the project initially included me, in January and February, and two post-graduate students in anthropology from the University of Brasilia in July of that same year, in a survey of indigenous people in prisons in Roraima state. Over the years, since then, I have continued interviews with indigenous people in prison, which have contributed to a political awareness of their differentiated rights as indigenous people, following both national and international legislation. The research has led to mobilizations, among some prisoners, to demand that their differentiated rights as indigenous people be respected. Currently, the Macushi PhD student in anthropology at the University of Brasília, Léia da Silva Ramos, is doing research, within my project, on indigenous people in prison in Boa Vista, with very positive results. A school teacher widely known in the Raposa Serra do Sol Indigenous Land and also within the indigenous community in Boa Vista, she is seen as an indigenous scholar who knows personally some of the indigenous people in prison and thus has privileged access to information.

Over the past years, the current Federal Deputy, Joênia Batista de Carvalho (Wapishana) (elected in 2018), previously indigenous lawyer of the CIR, together with some indigenous law students in Roraima, started to organize meetings in communities on indigenous lands to write down indigenous internal regiments so that communities may solve many problems on their own lands, thereby reducing the numbers of people sent to prison. In early October 2019, the Law Tribunal of Roraima (TJRR) reactivated the first Indigenous Conciliation Pole (Polo Indígena de Conciliação) in Brazil, installed in the Raposa Serra do Sol Indigenous Land in 2015 in Mataruca community, Uiramutã, which aims to help solve internal conflicts between indigenous people without depending on the immediate interference of the national justice system. Over the past decades, the indigenous leader of Uiramutã, Orlando Pereira da Silva, has been calling meetings of the Council of Tuxauas (local leaders) to sentence indigenous people under decisions made locally by the leaders, with very effective results, thereby contributing to keeping people out of the prison system. However, in crimes seen as being heinous, such as homicide or rape, the local leaders often call the police, since the family of the victim will not always accept local interference.

16 G1 Roraima, Boa Vista, 03/08/2021, <https://g1.globo.com/rr/roraima/noticia/2021/08/03/intervencao-federal-na-penitenciaria-agricola-de-rr-e-prorrogada-pela-12a-vez.ghtml Access on 15/09/2021. 
An ethnographic study undertaken by Bruce Miller (2001), on the Northwest coast of North America in Canada and the USA, examines the issue that for indigenous peoples of North America the history of colonialism has frequently led to a loss or distorted sense of their own native practices of justice, and examines ways in which contemporary native communities have dealt with this dilemma. His study examines ways in which Coast Salish indigenous communities have struggled to reestablish control over justice in the face of conflicting pressures resulting from a long colonial history. Looking at different communities, the Upper Skagit Indian Tribe in Washington State, the Stó:lo Nation in British Columbia, and the South Island Tribal Council on Vancouver Island, Miller shows how each of these communities has taken its own direction in establishing a system of tribal justice. This example is comparable to the recent efforts of Joênia Wapichana, in the northeast of Roraima, Brazil, where indigenous people have experienced the violent processes of colonization and slavery since the late XVIII century, to write down internal regiments for each local group of communities, aiming at indigenous sovereignty within the State, associated with controlled justice programs.

In view of the aggressively anti-indigenous policies of the Bolsonaro government, aimed at dismantling indigenous rights and also environmental legislation to encourage the invasion of indigenous territories, demarcated or not, the protagonism of indigenous organizations at the national and regional level has become the principal tool to defend their rights against these onslaughts, together with community actions at the local level. In the prison system of Roraima, mobilizations among indigenous people in prison aim to bring their rights into effect against the genocidal practices of criminalizing and imprisoning native peoples.

Received: January 28, 2021

Approved: September 08, 2021

* A preliminary version of this paper was presented at Session 5-0155, Indigenous Peoples, Tribunals, Prisons, and Legal and Public Processes, in the CASCA/AAA Annual Meeting, and was sponsored by the Canadian Anthropology Society (CASCA) and cosponsored by the Association for Political and Legal Anthropology, 23 November 2019, organized by professor Bruce Granville Miller (University of British Columbia) and Stephen Grant Baines (Universidade de Brasilia), 2019, at the Vancouver Conference Centre, Canada. I received funding from the CAPES Print to spend ten days in Canada, including participation in the CASCA/AAA Meeting. 


\section{Bibliographical References}

BAINES, Stephen G. 2006. "Entre dois estados nacionais. Perspectivas indígenas a respeito da fronteira entre Guiana e Brasil”, Anuário antropológico, 2005: 35-49.

BAINES, Stephen G. 2009. "Esperando para ser julgado. Indígenas no sistema penitenciário de Boa Vista em Roraima”. In: M. I. Smiljanic, J. Pimenta and S. G. Baines (eds.), Faces da indianidade. Curitiba: Nexo Design. pp. 169-186.

BAINES, Stephen G. 2016a. "A situação prisional de indígenas no sistema penitenciário de Boa Vista, Roraima”. Vivência: Revista de Antropologia, 1: 143-155.

BAINES, Stephen. G. 2016b, “Disrespecting Indigenous Rights in the prison system of Roraima state, Brazil”. Études Rurales, 196: 109-126.

BRASIL. Supremo Tribunal Federal (STF). "Arguição de Descumprimento de Preceito Fundamental (ADPF) no 709/DF”. Rel. Min. Luís Roberto Barroso. Brasília, DF, o8 de julho de 2020.

CARDOSO DE OLIVEIRA, Roberto. 1996. O Índio e o mundo dos brancos. Campinas, São Paulo: Editora da UNICAMP. $4^{\text {a }}$ edição.

CARDOSO DE OLIVEIRA, Roberto. 2005, "Introdução". In: CARDOSO DE OLIVEIRA, Roberto; BAINES, Stephen (Orgs.), Nacionalidade e Etnicidade em Fronteiras. Brasília, Editora da UnB, 278p. (Coleção Américas, Coordenação Ana Maria Fernandes), pp. 9-2o.

ELOY AMADO, Luiz Henrique (ed.). 2020. Justiça Criminal e Povos Indígenas no Brasil. São Leopoldo: Karywa.

FARAGE, Nádia. 1991. As muralhas dos sertões. Os povos indígenas no Rio Branco e a colonização. Rio de Janeiro: Paz e Terra/Anpocs.

FOUCAULT, Michel. 1995 [1979]. Discipline and Punish. The Birth of the Prison. New York: Vintage Books.

GOFFMAN, Erving. 1990 [1974]. Asylums. Essays on the Social Situation of Mental Patients and Other Inmates. Garden City (New York): Anchor Books.

JUCÁ, Felipe Pereira. 2019. Justiça e Povos Indígenas: análise crítica de processos criminais em São Gabriel da Cachoeira/Amazona. Master's dissertation, Post-Graduate Program in Social Anthropology, Federal University of Amazonas (UFAM), Manaus.

MILLER, Bruce Granville. 2001. The Problem of Justice: Tradition and Law in the Coast Salish World. Lincoln: University of Nebraska Press.

MOREIRA DA SILVA, Tédney. 2015. No banco dos réus, um índio: criminalização de indígenas no Brasil. Masters's dissertation, Law Faculty, University of Brasilia (UnB), Brasilia.

PACHECO DE OLIVEIRA, João. 1997. "Pardos, Mestiços ou Caboclos: os índios no censos nacionais no Brasil (1872-1980)". Horizontes Antropológicos, 6: 61-84.

PACHECO DE OLIVEIRA, João. 1999, “Entrando e saindo da 'mistura'. Os Índios nos censos nacionais”. In: J.P. de Oliveira (ed.), Ensaios em antropologia histórica. Rio de Janeiro: Editora da UFRJ. pp. 124-151.

QUIJANO, Anibal. 2000, "Coloniality of Power, Eurocentrism, and Latin America", Nepentla. Views From the South, 1(3): 533-580.

SANTILLI, Paulo. 2002. "Trabalho escravo e brancos canibais. Uma narrativa histórica Macuxi”. In: B. Albert and A. Ramos (eds.), Pacificando o branco. Cosmologias do contato no Norte-Amazônico. São Paulo: Editora da UNESP. pp. 487-505.

SANTOS, Jonildo Viana dos. 2004. Relações sociais e mecanismos de conflito na Penitenciária Agrícola de Monte Cristo. Bachelor of Arts dissertation in Social Science, Anthropology. Boa Vista: Universidade Federal de Roraima. 
TEÓFILO DA SILVA, Cristhian. 2009. “Criminalização Indígena e abandono legal: aspectos da situação penal dos Índios no Brasil”. In: C. Teófilo da Silva; A. C. de Souza Lima; S. G. Baines (eds.), Problemáticas Sociais para Sociedades Plurais: políticas indigenistas, sociais e de desenvolvimento em perspectiva comparada. São Paulo: Annablume; Distrito Federal: FAP/DF. pp. 209-222.

TEÓFILO DA SILVA, Cristhian. 2013. "O índio, o pardo e o invisível: primeiras impressões sobre a criminalização e o aprisionamento de indígenas no Brasil”. Antropolítica, 34: 137-158.

\section{Stephen Grant Baines}

https://orcid.org/0000-0002-9232-8737

Full professor of Anthropology, University of Brasília; Researcher PQ-1A, Brazilian National Council for Scientific and Technological Development (Conselho Nacional de Desenvolvimento Científico e Tecnológico - CNPq).

Address for correspondence: Stephen G. Baines, Caixa Postal 04495, AC / EQN 204/404, Lote Único, 70842-970 - Brasília - DF, Brazil

Email: stephengbaines@gmail.com 